\title{
Pulmonary surfactant in COVID-19; A role in etiology and treatment
}

\author{
Myasar Alkotaji ${ }^{1}$, Musab M. Khalaf ${ }^{2}$
}

College of pharmacy, University of Mosul, Mosul-Iraq

${ }^{1}$ Corresponding author: myasar.alkotaji@uomosul.edu.iq.

Abstract

Received accepted

15.11.2020 30.11.2020

Introduction: Today, SARS-COV-2 infection represents a global threat. Dealing with this viral infection necessitates a comprehensive understanding of pathophysiology of the disease to reach to the suitable treatment. Treatment of this disease should not be restricted to the usual antiviral treatments, which suffered from several limitations including low effectiveness, development of virusresistant mutations and the unwanted side effects.

Knowing that SARS-CoV-2 attack the machinery unit of production of surfactant in the lung, the alveolar type II cells, manifested the importance of this review article on the role of pulmonary surfactant in this disease and the possible role of pulmonary surfactant that can play in treating of COVID-19 patients.

Objective: This work tried to clarify the important role of pulmonary surfactant in lung physiology and possible immune-modulatory effect. In addition, the constituents of pulmonary surfactant and their roles against COVID-19 complications is highlighted. This article suggested that surfactant therapy may have a role in COVID-19 therapy and this can be in a form of exogenous (synthetic) surfactant administrated through endotracheal tube or through aerosolization. The pros and cons of these methods of administration have been discussed. Moreover, a possible way of stimulation of endogenous surfactant by administrating a drug that stimulates the synthesis of surfactant has been suggested.

Key words: Pulmonary surfactant, COVID-19, synthetic surfactant, alveolar type II cells 


\section{العوامل السطية الرئوية في مرض كوفيد-19, الدور المحتمل في المرض والعلاج}

تمثل الإصابات بفايروس كرورنا المستجد تهديدا عالميا. ان التعامل مع هذه الاصابات الفيروسية يتطلب فهما شاملا للفسيولوجيا المرضية لهذا المرض كي نصل الى العلاج المناسب. ان علاج هذا المرض يجب أن لا ينحصر بمضادات الفايروسات الاعتيادية و التي تعاني من العديد من القصور كقلة الفعالية بالإضافة الى الطفرات المقاومة للدواء والأعر اض الجانبية غير المرغوب بها. ان الإحاطة علما بأن فايروس كورونا المستجد (SARS-CoV-2) يهاجم وحدة أنتاج العوامل السطحية (surfactant) في الرئة والمتمثلة بالخلايا الحويصلية من النوع الثاني يبين بجلاء أهمية هذا البحث حول دور العوامل السطحية الرئوية في هذا المرض و الدور المحتمل للعوامل السطحية الرئوية الذي ممكن ان تلعبه في علاج مرضى كوفيد-19.

يحاول هذا البحث توضيح الدور المهم للعو امل السطحية الرئوية في تنظيم وظيفة الرئة والدور المناعي المرتقب. بالإضافة الى ذلك يهدف البحث الى تقديم اضاءات حول مكونات العوامل السطحية الرئوية ودورها المضاد لتعقيدات الإصابة بكوفيد19.تخلص هذه الورقة العلمية الى الاقتر اح بأن العلاج بالعوامل السطحية الرئوية يمكن أن يلعب دورا في علاج كوفيد-19 و الذي يتمثل بالعو امل السطحية الرئوية الخارجية أو المصنعة والتي يمكن اعطاءها عن طريق الضخ المباشر عبر أنبوب من خلال القصبة الهو ائية أو من خلال طريقة التبخير. بالإضافة لذلك تم مناقتشة ايجابيات وسلبيات طرق الإعطاء هذه. علاوة على ذلك تقدم هذه الورقة العلمية اقتر اح تحفيز تصنيع المزيد من العو امل السطحية الرئوية في الرئة وذلك بإعطاء دواء ذو قابلية لتحفيز عملية تصنيع هذه العو امل في داخل الرئة.

\section{Introduction}

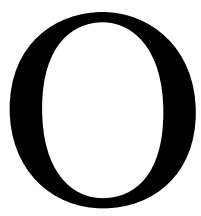

ne of the many pathogens that infect the respiratory system of animals and humans is a coronavirus. This family of viruses was the cause of two former outbreaks including the severe acute respiratory syndrome (SARSCoV) in China in 2003, and the Middle East Respiratory Syndrome (MERS-CoV) which was first reported in Saudi Arabia in 2012.

Both of these outbreaks were considered previously as a great threat to public health; however, they were not considered a pandemic. In December 2019, a varying number of patients have admitted to hospitals with the initial diagnosis was pneumonia of mysterious reason ${ }^{1,2}$. Later, these patients were found to be infected with a novel series of 
coronavirus defined as "SARS-CoV2". This new disease caused by coronavirus was named by WHO COVID-19 ${ }^{3}$. Later on, the WHO considered this disease a pandemic. The source of SARS-CoV-2 is unknown, however, some genetic studies assumed that SARS-CoV-2 might be a result of a combination of two viruses including a bat SARS-like $\mathrm{CoV}$ and a coronavirus of unknown origin ${ }^{4}$.

\section{Pathophysiology of SARS-CoV-2 infection}

The initial step of viral infection is the binding of the virus to the host surface receptors and then the virus will fuse with the cytoplasmic membrane. It is well known that the main target of the virus in epithelial cells of the lung. The sequence of binding of SARSCoV-2 spikes is similar to what is happened with SARS-CoV where the entry of the virus into the host cells occurs after binding of the virus to the
ACE2 receptors on the cell membrane 5 .

After some stages of progression of the disease, the virus reaches the alveoli (the gas exchange units of the lung) and infects alveolar type II cells. Both SARS-CoV and SARS-CoV-2 infect, specifically, the alveolar type II cells more than alveolar type I cells 6,7. SARS-CoV proliferates inside type II cells and this leads to the production and releases a lot of viral particles which damage the cells and may lead to cellular death ${ }^{8}$. The viral replication will continue and extend to adjacent cells and infect type II cells in the invading areas. When this occurs, a large number of type II cells will be lost ${ }^{9,10}$. Knowing that alveolar type II cells are a precursor for type I cells explains the huge effect of the virus on the physiological role of alveoli and the consequent respiratory complication.

The pathologic consequence of SARS and SARS-CoV-2 infection is 
widespread damage of the alveoli, where the hyaline membranes become rich in fibrin with the presence of a few multinucleated giant cells ${ }^{11,12}$. The irregular healing of the wound may lead to severe scarring and fibrosis. Retrieval of lung function will require epithelial regeneration and intense acquired and innate immune response. It was found that administrating epithelial growth factors like keratinocyte growth factor to COVID-19 patients might be harmful and might increase the viral load by producing more ACE2 expressing cells ${ }^{13}$. The risk of COVID-19 is particularly high for elderly individuals where the immune response is diminished and there is a decline in the ability to reform the damaged epithelium. besides, in elderly there is a reduction in the mucociliary clearance and this may permit the virus to propagate in the alveoli of the lung more readily ${ }^{14}$. Although that most COVID-19 cases are mild and required no treatment, however, in some cases $(5.37 \%$ of those aged under 60 years compared to $16.91 \%$ of those above 60 ) the disease progressed into what is known as Acute respiratory distress syndrome (ARDS) ${ }^{15}$. Acute respiratory distress syndrome and acute lung injury (ALI) are popular diseases, required highly expensive intervention and they are potentially fatal diseases with mortality rates of about $40 \%$. They are characterized by acute respiratory failure with widespread, bilateral injury of the lung and severe hypoxemia. There are many clinical conditions associated with the development of ARDS, such as pneumonia, sepsis, aspiration of gastric contents and major trauma ${ }^{16}$. Unfortunately, this pulmonary damage may increase alveolar endothelial-epithelial permeability, leading to flooding of the alveoli, decrease lung function, and deprive the lungs of adequate quantities of surfactant ${ }^{17}$. 


\section{Pulmonary surfactant}

Pulmonary surfactant is a lipid-rotein complex ${ }^{18}$, that is secreted by special cells of the alveolar epithelium. Pulmonary surfactant is assembled and secreted onto the respiratory surface to play a dual function in innate defense mechanism and biophysical stability of the membrane of alveoli. Alveolar epithelial type II cells are the cells that are responsible for the production of pulmonary surfactant. After production, a surfactant is transported to what is called lamellar bodies where the lipids and proteins are combined and stored before it can be secreted ${ }^{19}$.

It is well known that pulmonary surfactant is responsible for reducing the surface tension, at the air-water interface, of the intraluminal alveoli and prevent the collapse of the alveoli 20. However, pulmonary surfactant represents a primary defense mechanism against the entry of pathogenic microorganisms into the lung. Surfactants have a role in mucociliary clearance since surfactants are responsible for the displacement of particles into the liquid phase, which is followed by subsequent processes of defense mechanisms including the movement of particles out of the lungs or ending the particles into lymphatic glands 19,21 .

Composition of pulmonary surfactant

Pulmonary surfactant composition includes about $80 \%$ phospholipid, 5$10 \%$ neutral lipids, which is mainly cholesterol, 8-10\% proteins, and 5$6 \%$ specific surfactant proteins ${ }^{22}$. It is worthy to mention that the phospholipid, dipalmitoyl phosphatidylcholine (DPPC) represents about $30-65 \%$ of the pulmonary surfactant. Alao, surfactant contains other saturated phosphatidyl cholines (PC), such as palmitoylmirystoyl phosphatidyl choline (PMPC) and unsaturated PCs, 
such as palmitoyl oleoyl-PC (POPC) 23.

One of the important key constituents of pulmonary surfactant is cholesterol, which accounts for about $3-8 \%$ of the total mass under normal physiological conditions ${ }^{24}$. The proportion of cholesterol in surfactant might affect its function. A study in 2016 demonstrated that the presence of a high concentration of cholesterol, above the physiological levels of cholesterol, might lead to the impairment of surface tension reduction from injured lungs ${ }^{25}$.

Indeed, it is not only the percentage of different compositions that is important in the effective functioning of the surfactant, but the orientation of phospholipid is also important. Phospholipids of surfactant are oriented in a state of matter called liquid crystal (LC). Dipalmitoyl phosphatidyl choline, the main constituent of the lung surfactant, has an LC transition temperature of 41- $42^{\circ} \mathrm{C}$, which is above the body temperature. At body temperature $\left(37^{\circ} \mathrm{C}\right)$, DPPC exists as a rigid gel phase, which plays an important role in reducing the surface tension of the alveolar interface to very low values during dynamic compression ${ }^{26,27}$.

\section{Membrane-associated surfactant proteins}

Four surfactant proteins are involved in pulmonary surfactant-associated functions including SP-A, SP-B, SPC, and SP-D 28. The first three proteins are called apolipoproteins because they are associated with surfactant phospholipids. SP-D is not considered apolipoprotein although it interacts with phospholipids under specific conditions. Both SP-A and SP-D proteins play a role in the intrinsic immune defense system while the hydrophobic proteins (SP-B and SP-C) are involved in the surface activity of surfactant. However, the importance of the contribution of these proteins in surfactant ability is 
varied. It is known that SP-B is the most important protein in pulmonary surfactant for maintaining respiratory function. Experiments showed that deactivation of the SP-B gene expression results in respiratory failure at birth. This is due to the impossibility of maintaining the physiological function of the lungs ${ }^{28}$. In addition, the net positive charge of SP-B might increase its interaction with anionic phospholipids. Moreover, the sort of orientation of some proteins in the membrane surface may enhance the binding with A phospholipid, for example, the parallel orientation to the surface of the membrane will maintain a sort of hydrophobic interactions between the helical sectors (the amphipathic sectors) and the surface of the membrane ${ }^{29}$.

In contrast to SP-B and SP-C, both SP-A and SP-D proteins have a hydrophilic nature and can be considered as components of the innate immune system that modulates the inflammatory response and aids in removing microbes from the respiratory epithelial surfaces. In addition, SP-A and SP-D showed intrinsic antimicrobial activity ${ }^{30}$. The surfactant immune mechanism is not implemented against bacterial infection only. Fungal and viral infections are implemented as well. The surfactant will act through facilitating the uptake of these foreign molecules and enhance the phagocytosis process leading to the elimination of these invading microorganisms. The surfactant proteins SP-A and SP-D have the abilities to attach to both types of bacteria, the Gram-negative and Gram-positive bacteria ${ }^{31,32}$. The coexistence of SP-A and SP-D on the mucous membrane of the respiratory tract and alveoli aids in the aggregation of influenza $A$ virus particles and enhances the neutrophil attack on virus ${ }^{33,}{ }^{34}$. Moreover, the SP-D, which is available in lung and 
respiratory fluid, can bind to the envelope protein of the human immune deficiency virus (HIV) and inhibits the in-vivo multiplication of this virus ${ }^{35}$. Very interestingly, a study published in 2007 demonstrated that the lung surfactant-associated protein (collectin SP-D) can bind to SARS-CoV spike-protein, specifically, to the glycoprotein of the spike of SARS-CoV ${ }^{36}$. This highlights the possible role of surfactant in the defense mechanism against coronavirus.

\section{Abnormalities of pulmonary surfactant}

As mentioned before SARS-CoV-2 is known to be capable of infecting type II alveolar cells, the pneumocytes that are responsible for the production of surfactant. Abnormalities of lung surfactant can produce intense lung injury and they are associated with loss of stability of the alveoli, floating, and alveolar breakdown. These alveolar dysfunctions have been noticed in infant respiratory distress syndrome (IRDS) and acute respiratory distress syndrome (ARDS) $37,38,39$. The main abnormalities that occur with a surfactant include an about $80 \%$ decline in the overall phospholipid content, decrease in the surfactant content of dipalmitoyl phosphatidylcholine (DPPC) and phosphatidylglycerol and other fractions, and decrease of apoproteins contents ${ }^{37,38}$.

The surfactant lacks or deficiency due to block of surfactant synthesis in type II alveolar cells might be the reason for the sudden deterioration of respiratory function in COVID-19 patients. Therefore, treatment with a synthetic surfactant that may aid in renewal or replacement of the depleted endogenous surfactant storage may provide a strong biologic and physiologic plausibility for the use of exogenous surfactant therapy in COVID-19-related ARDS.

\section{Surfactant replacement therapy}


Exogenous-surfactant replacement therapy has been tried with great success in IRDS ${ }^{39}$ while studies in adult respiratory distress syndrome have had dissimilar results. Initial reports about using surfactant in adult respiratory distress syndrome have shown that artificial exogenous surfactant (Exosurf $\AA)(40)$ or bovine surfactant (Survanta $\left.{ }^{\circledR}\right){ }^{41}$ can improve oxygenation and lung function.

In one study, the authors mentioned the results of a large, prospective, multicenter trial involving 725 patients with adult respiratory distress syndrome induced by sepsis and treated with Exosurf ${ }^{\circledR}$ or placebo. The obtained results demonstrated that exogenous-surfactant supplementation did not cause an amelioration in patients condition ${ }^{42}$.

There are many explanations for the failure in the improvement of patients with adult respiratory distress syndrome in the Exosurf ${ }^{\circledR}$ trial. The first explanation may be related to the causative condition that may lead to adult respiratory distress syndrome ${ }^{43}$. For example, in the study conducted by Gregory et al., the patients who participated in the study had different etiologies that lead to adult respiratory distress syndrome whereas the Exosurf® study was restricted to sepsis-induced adult respiratory distress syndrome. Therefore, the causative factor of adult respiratory distress syndrome may have to be taken into consideration in future studies ${ }^{41}$.

The second important explanation for the variations in the exogenous surfactant efficacy may be related to the type of surfactant preparation that was used. Exosurf® is a type of exogenous surfactant that does not contain apoproteins that normally present in natural surfactant and this can affect the onset of action of surfactant ${ }^{43}$.

Whereas the study of Gregory et al. used a bovine surfactant that contains 
two apoproteins constituents, the synthetic preparation does not contain these apoproteins. These obtained data indicated that any surfactant preparation must contain apoproteins to be effective ${ }^{44}$.

Another important thing in surfactant therapy is the mode of delivery of surfactant. In the Exosurf ${ }^{\circledR}$ trial ${ }^{42}$, surfactant was administered by continuous aerosolization, the study conducted by MacIntyre et al. ${ }^{45}$ demonstrated that only a small amount of aerosolized surfactant (about $4.5 \%$ ) was delivered to the lungs. The problem with this route of administration is that the small quantity of delivered surfactant has no therapeutic effect because it undergoes inhibition by the similar inflammatory mediators that are linked with ARDS. There are previous negative results with the use of surfactant in ARDS, where patients failed to express noticeable benefit as the therapy failed to reach its intended target in the adult lung.

Another way of administration of exogenous surfactant is direct administration through a bronchoscope. Gunther et al. ${ }^{46}$ used natural bovine surfactant (Alveofact ${ }^{\circledR}$ ) in a dose of $300 \mathrm{mg} / \mathrm{kg}$ of body weight administered through fibreoptic bronchoscope, which delivered surfactant to each segment of lung. This study demonstrated that using the fibreoptic bronchoscope to deliver surfactant had no harmful effects on lung function or hemodynamics. Within 12 hours of administration, these patients had a substantial improvement in oxygenation, although deterioration in gas exchange has been noted in seven patients; for these seven patients, the additional amount of surfactant was administered within the first $24 \mathrm{~h}$. There was a substantial decline in mortality in these patients. This study provides additional supports for the 
idea that larger amounts of surfactant is necessary to be administered to produce a therapeutic effect.

Other researchers have suggested that administration of surfactant by bronchoscopic installation provides two advantages including the delivery of a large amount of surfactant and allows the clinician to perform a bronchoalveolar lavage which aid in removing inflammatory mediators 47 .

Recently, a new product named KL4 was introduced by Windtree Therapeutics. Aerosolized KL4 is a synthetic surfactant with an amphipathic peptide and it was used successfully in RDS in premature infants. Windtree Therapeutics company announced to conduct a clinical trial on KL4 as a potential therapeutic for ARDS in patients with COVID-19, however, no results is published yet ${ }^{48}$.

Interestingly and very recently, the first clinical trial on using of synthetic surfactant in adult respiratory distress syndrome in COVID-19 was registered on clinicaltrial.gov/ct2/show/M. In this controlled study, twenty COVID-19induced respiratory failure patients will be randomized to receive either the Bovine lipid extract surfactant with standard care or the standard care alone. The product will be administered through the endotracheal tube directly to the lung and the treatment will be repeated for three days. The anticipated results of this study will be available at the beginning of 2021.

In the meantime, we are suggesting a better alternative, a drug with the ability to enhance the synthesis and secretion of endogenous surfactant from its source (the alveolar type II cells). However, this is recommended in patients with mild to moderate cases of COVID-19, where the alveolar type II cells are not completely distressed. This article suggests early treatment of COVID- 
19 patients with a very high dose of Ambroxol. Ambroxol is a mucolytic agent that stimulates the secretion of surfactant which will aid in mucociliary clearance of the virus in addition to the surfactant role in preventing the collapse of alveoli and prevention of the subsequent complication. Ambroxol is an approved drug in many European countries and its unique action on stimulating the secretion of surfactant from alveolar type II cells is well documented ${ }^{49}$. Also, Ambroxol has been used in the treatment of neonatal ARDS and it demonstrated the antiinflammatory effect that might be useful in COVID-19 patients. In addition, Ambroxol manifested an invitro inhibitory action on rhinovirus infection of the human tracheal cell line, which is one of the common respiratory tract infections ${ }^{50}$. Very recently, a non-peer-reviewed work demonstrated the in-vitro effectiveness of clinically-relevant concentration of Ambroxol on SARS-
CoV-2 in Vero cell line ${ }^{51}$. This result is in accordance of a newly published article that suggested Ambroxol as a potential therapy for SARS-CoV-2 and assumed that it works in a similar mechanism to azithromycin 52 . Altogether there is a need for further experimental work on Ambroxol to confirm the proposed action of Ambroxol in COVID-19 patients.

\section{Conclusion}

The respiratory complications encountered with the severe cases of COVID-19 respiratory illness motivates the sense about the possibilities of using synthetic surfactant in treating COVID-19 ARDS patients. This article highlighted the structure and physiology of surfactant, the role of surfactant in respiratory distress in general and surfactant role in the etiology of COVID-19.

The history of long years of successful management of RDS in 
premature infants with surfactant, especially the natural surfactant, is encouraging. However, although the feasibility, and safety encountered with the use of surfactant in ARDS in infants is very clear, there is no obvious benefit from using of surfactant in ARDS in adults., The real problem with a surfactant therapy is in the critical components of the surfactant.

The natural surfactant of animal origin is closely similar to human surfactant; however, they lack certain essential proteins or certain components that they lose during the extraction process. The real challenge with the synthetic surfactant is with obtaining optimum composition, which resembles the natural surfactant constituents, especially the apoproteins constituents.

To conclude, optimum surfactant composition is very important to achieve an ideal therapeutic response and must contain apoproteins. In addition, the method of delivery of surfactant is critical for achieving adequate concentration of the product in all lung segments. Moreover, the surfactant should be administered in a large amount to achieve a perfect therapeutic response.

The potential role of surfactant in COVID-19 needs more investigations and this should include interdisciplinary teams working together to reach the suitable synthetic surfactant with a suitable dosage form to be administered at suitable time of the infection. Alternatively, the suggested drug, Ambroxol, may achieve the goal by enhancing the production of endogenous surfactant. However, further investigation of the Ambroxol effect in COVID-19 is required in order to prove this supposed role in COVID-19 treatments. 


\section{Acknowledgment:}

The authors would like to thank the College of pharmacy-University of Mosul.

\section{References}

1- Bogoch, A. Watts, A. ThomasBachli, C. Huber, M.U.G. Kraemer, K. Khan, Pneumonia of unknown etiology in Wuhan, China: potential for international spread via commercial air travel, J. Trav. Med. 2020; https://doi.org/10.1093/jtm/ taaa008.

2- H. Lu, C.W. Stratton, Y.W. Tang, Outbreak of pneumonia of unknown etiology in Wuhan China: the mystery and the miracle, J. Med. Virol. 2020; 92 401-402, https://doi.org/10.1002/jmv.2567 $\underline{8}$.

3- S. Zhao, Q. Lin, J. Ran, S.S. Musa, G. Yang, W. Wang, et al., Preliminary estimation of the basic reproduction number of novel coronavirus (2019-nCoV) in China, from 2019 to 2020: a data-driven analysis in the early phase of the outbreak, Int. J.
No fund or grant has been received in this work at all.

Conflict of interest: There is no conflict of interest.

Infect. Dis.: 2020; 92, 214-217, https://doi. org/10.1016/j.ijid.2020.01.050.

4- AM. Al-Alim, M.A Hamad and A.A.AL-ledani. Some insights of novel COVID-19 virus:structure, pathogenicity and immunity aspects. Iraqi Journal of Veterinary Sciences 2020; 34, 2, 287-293.

5- Y. Wan, J. Shang, R. Graham, R.S. Baric, F. Li, Receptor recognition by novel coronavirus from Wuhan: an analysis based on decade-long structural studies of SARS, J. Virol. 2020; https://doi.org/10.1128/JVI.0012 7-20.

6- Mossel EC, Wang J, Jeffers S, et al. . SARS-CoV replicates in primary human alveolar type II cell cultures but not in type I-like cells. Virology 2008; 372:127135. doi:10.1016/j.virol.2007.09.045

7- Weinheimer VK, Becher A, Tonnies $\mathrm{M}$, et al. . Influenza A 
viruses target type II pneumocytes in the human lung. J Infect Dis 2012; 206: 1685-1694. doi:10.1093/infdis/jis455

8- Qian Z, Travanty EA, Oko L, et al. . Innate immune response of human alveolar type II cells infected with severe acute respiratory syndromecoronavirus. Am J Respir Cell Mol Biol 2013; 48: 742-748. doi:10.1165/rcmb.2012-0339OC

9- Kumar PA, Hu Y, Yamamoto Y, et al. . Distal airway stem cells yield alveoli in vitro and during lung regeneration following H1N1 influenza infection. Cell 2011; 147：525538.

doi:10.1016/j.cell.2011.10.001

10- Yee M, Domm W, Gelein R, et al. Alternative Progenitor Lineages Regenerate the Adult Lung Depleted of Alveolar Epithelial Type 2 Cells. Am J Respir Cell Mol Biol 2017; 56: 453-464.

doi:10.1165/rcmb.2016-0150OC

11-Gu J, Korteweg C. Pathology and pathogenesis of severe acute respiratory syndrome. Am J Pathol 2007; 170: 1136-1147. doi:10.2353/ajpath.2007.061088
12- Xu Z, Shi L, Wang Y, et al. . Pathological findings of COVID-19 associated with acute respiratory distress syndrome. Lancet Respir Med 2020.

13- Nikolaidis NM, Noel JG, Pitstick LB, et al. . Mitogenic stimulation accelerates influenza-induced mortality by increasing susceptibility of alveolar type II cells to infection. Proc Natl Acad Sci USA 2017; 114: E6613E6622. doi:10.1073/pnas.1621172114 14- Ho JC, Chan KN, Hu WH, et al. . The effect of aging on nasal mucociliary clearance, beat frequency, and ultrastructure of respiratory cilia. Am J Respir Crit Care Med 2001; 163: 983-988. doi:10.1164/ajrccm.163.4.990912 1

15- Lian J, Jin X, Hao S, Cai H, Zhang S, Zheng L, et al. Analysis of Epidemiological and Clinical Features in Older Patients With Coronavirus Disease 2019 (COVID-19) Outside Wuhan. Clin Infect Dis [Internet]. [cited 2020 May 5]; Available from: http://academic.oup.com/cid/adva nce- 
article/doi/10.1093/cid/ciaa242/5

$\underline{811557}$

16- Ware LB and Matthay MA: The acute respiratory distress syndrome. N Engl J Med 2000; 342: 1334-1349,.

17- Villar J, Kacmarek RM, PerezMendez L and Aquierre-Jaime A: A high positive end-expiratory pressure, low tidal volume ventilatory strategy improves outcome in persistent acute respiratory distress syndrome: a randomized, controlled trial. Crit Care Med 2000; 34: 1311-1318.

18-Clements, J.A., . Surface tension of lung extracts. Proc. Soc. Exp. Biol. Med. 1957; 95 (1), 170-172.

19- Wright JR, Immunoregulatory functions of surfactant proteins, Nat. Rev. Immunol. 2005; 5 5868.

20- SeungHye Han and Rama K. Mallampalli. The Role of Surfactant in Lung Disease and Host Defense against Pulmonary Infections Ann Am Thorac Soc. 2015 ; 12(5): 765-774

21- Wochenschr SM. The mucociliary system of the lung-role of surfactant 2000 ;130(19):691-8.
22-Goerke J. Pulmonary surfactant: functions and molecular composition, Biochim.

Biophys. Acta 1998; 79-89, 1408.

23-Bruce A Holm, Zhengdong Wang, Edmund A Egan and $\mathrm{H}$ Notter Robert Content of Dipalmitoyl Phosphatidylcholine in Lung Surfactant: Ramifications for Surface Activity Pediatric Research volume $1996 ; 39, \mathrm{pp}$ 805-811

24- Andreas Gunther, Reinhold Schmidt, Andreas Feustel, Ute Meier, Caroline Pucker et al. Surfactant Subtype Conversion Is Related to Loss of Surfactant Apoprotein B and Surface Activity in Large Surfactant Aggregates Experimental and Clinical Studies. American journal of respiratory and critical care medicine 1999; 159, pp 244251 .

25-Scott Milos, Josh Qua Hiansen, Cory Yamashita and Ruud Veldhuizen. The Role of a High Cholesterol Diet on Surfactant Biophysics during Acute Lung Injury2016; 1297.1 
26- K. Nag, K.M. Keough, Epifluorescence microscopic studies of monolayers containing mixtures of dioleoyl- and dipalmitoyl phosphatidyl cholines, Biophys.

$$
\text { J. } 65 \text { 1993; 1019-1026. }
$$

27- J. Johansson, T. Curstedt, Molecular structures and interactions of pulmonary surfactant components, Eur. J. Biochem. 1997; 244 , 675693.

28- J.C. Clark, S.E. Wert, C.J. Bachurski, M.T. Stahlman, B.R. Stripp, T.E. Weaver, J.A. Whitsett, Targeted disruption of the surfactant protein B gene disrupts surfactant homeostasis, causing respiratory failure in newborn mice, Proc. Natl. Acad. Sci. U. S. A. 1995; 92, 7794 7798

29- Senthil K.

Kandasamy and Ronald G. Larson.

Molecular Dynamics Study of the Lung Surfactant Peptide SP-B ${ }_{1-25}$ with DPPC Monolayers: Insights into Interactions and Peptide Position and Orientation Biophys J. 2005 ; 88(3): 1577-1592.

30- Marnie A. Ryan, Henry T. Akinbi, Alicia G. Serrano, Jesus Perez-Gil, Huixing Wu, Francis X.
McCormack et al. Antimicrobial Activity of Native and Synthetic Surfactant Protein B Peptides J Immunol , 2006; 176 (1) 416-425.

31- Annapurna Nayak, Eswari Dodagatta-Marri,Anthony George Tsolaki, and Uday Kishore,J Clin Invest. An Insight into the Diverse Roles of Surfactant Proteins, SP-A and SP-D in Innate and Adaptive Immunity. 2003 ; 111(10): 15891602.

32- Huixing Wu, Alexander

Kuzmenko, Sijue Wan, Lyndsay Schaffer, Alison Weiss, et al Surfactant proteins A and D inhibit the growth of Gram-negative bacteria by increasing membrane permeability J Clin Invest. 2003; 111(10): 15891602. doi: $\underline{10.1172 / J C I 16889}$.

33- Hartshorn KL ${ }^{1}$, Sastry KN, Chang D, White MR, Crouch EC. Enhanced anti-influenza activity of a surfactant protein $\mathrm{D}$ and serum conglutinin fusion protein. Am J Physiol Lung Cell Mol Physiol. 2000 ;278(1):L908.

34- Qi, L., Kash, J.C., Dugan, V.G., et al. The ability of pandemic influenza virus hemagglutinins to induce lower respiratory pathology is associated with decreased surfactant protein $\mathrm{D}$ 
binding. Virology 2011; 412(2): 426434.

35- Meschi, J., Crouch, E.C., Skolnik, P., et al. Surfactant protein D binds to human immunodeficiency virus (HIV) envelope protein gp120 and inhibits HIV replication. J Gen virol 2005; 86(11): 3097-3107.

36- Leth-Larsen, R., Zhong, F., Chow, V.T., Holmskov, U. and Lu, J. The SARS coronavirus spike glycoprotein is selectively recognized by lung surfactant protein $\mathrm{D}$ and activates macrophages. Immunobiology 2007;212(3), pp.201-211

37 - Ashbaugh DG, Bigelow DB, Petty TL, Levine BE. Acute respiratory distress in adults. Lancet 1967;2:319-323.

38 -Lewis JF, Jobe AH. Surfactant and the adult respiratory distress syndrome. Am Rev Respir Dis 1993;147:218-233.

39- Avery ME, Mead J. Surface properties in relation to atelectasis and hyaline membrane disease. Am J Dis Child 1959;97:571-573.

40- Wiedemann H, Baughman R, de Boisblanc B, et al. A multi centered trial in human sepsis-induced ARDS of an aerosolized synthetic surfactant (Exosurf). Am Rev Respir Dis 1992; 145: A184.

41 -Gregory TJ, Steinberg KP, Spragg R, Gadek JE. Bovine surfactant therapy for patients with acute respiratory distress syndrome. Am J Respir Crit Care Med 1997; 155: 1309-1315.

42- Anzueto A, Baughman RP, Guntupalli KK, et al. Aerosolized surfactant in adults with sepsisinduced acute respiratory distress syndrome. N Engl J Med 1996;334:1417-1421.

43- Anzueto A. Exogenous surfactant in acute respiratory distress syndrome: more is better. Eur Respir J 2002; 19: 787-789.

44- Gilliard N, Heldt GP, Loredo J, et al. Exposure of the hydrophobic components of porcine lung surfactant to oxidant stress alters tension properties. J Clin Invest 1994; 93: 2608-2615.

45- MacIntyre NR, Coleman RE, Schuller FS, Zaccardelli D, Pattishall EN. Efficiency of the delivery of aerosolized artificial surfactant in intubated patients with the adult respiratory distress syndrome. Am J 
Respir Crit Care Med 1994; 149: A125.

46- Gunther A, Schmidt R, Harodt J, et al. Bronchoscopic administration of bovine natural surfactant in ARDS and septic shock: impact on biophysical and biochemical surfactant properties. Eur Respir J 2002; 19: 797-804.

47- Wiswell TE, Smith RM, Katz $\mathrm{LB}$, et al. Bronchopulmonary segmental lavage with surfaxin $\left(\mathrm{KL}_{4}{ }^{-}\right.$ surfactant) for acute respiratory distress syndrome. Am J Respir Crit Care Med 1999;160:1188-1195.

$48-$

https://www.ondrugdelivery.com/win dtree-therapeutics-to-study-its-kl4surfactant-for-covid-19-pulmonaryeffects/ Accessed on 25-June-2020.

49- Disse BG. The pharmacology of ambroxol-review and new results. Eur J Respir Dis 1987;153:255-62
50- Yamaya, M.; Nishimura, H.; Nadine, L. K.; Ota, C.; Kubo, H.; Nagatomi, R., Ambroxol inhibits rhinovirus infection in primary cultures of human tracheal epithelial cells. Arch Pharm Res 2014, 37 (4), 520-529.

51- Steven B Bradfute, Chunyan Ye, Elizabeth C Clarke, Suresh Kumar, Graham S Timmins and Vojo Deretic; ambroxol and ciprofloxacin show activity against sars-cov2 in vero E6 cells at clinically-relevant concentrations. version 1. bioRxiv. Preprint. 2020 Aug 11.

doi: $\underline{10.1101 / 2020.08 .11 .245100}$

52-Myasar Alkotaji, Azithromycin and Ambroxol as potential pharmacotherapy for SARS-CoV-2. International journal of antimicrobial agents, 2020,56 (6).

Doi.org/10.1016/j.ijantimicag.2020.10 6192 